LewiN, J. C. (1953). J. gen. Microbiol. 9, 305-313.

\title{
Heterotrophy in Diatoms
}

\author{
BY JOYCE C. LEWIN* \\ Osborn Botanical Laboratory, Yale University, New Haven, Conn., U.S.A.
}

SUMMARY: Forty-two bacteria-free cultures of pennate diatoms from fresh water or soil were tested for ability to grow heterotrophically with glucose as the sole carbon source. Thirteen of these isolates proved capable of growth under these conditions. They comprised seven isolates of Navicula pelliculosa, five of other different species of Navicula, and one of Nitzschia (?) fonticola.

One isolate of Navicula pelliculosa was tested for its ability to grow heterotrophically on any one of sixty organic compounds. Only glucose, glycerol, and fructose were found to be effective in supporting growth. Glucose was metabolized both in the dark, and in the light in the absence of $\mathrm{CO}_{2}$. Glycerol and fructose were not utilized in the dark, but supported growth in the light in the absence of $\mathrm{CO}_{2}$.

There is apparently no previous record that any chlorophyllous diatom has been cultivated successfully in the dark. Miquel (1892) found that certain species of diatoms which he obtained in pure culture would not develop either in the dark or in semi-darkness on organic nutrient solutions, although they retained the power of proliferation when returned to the light after several months in darkness. Benecke (1900) observed no increase in numbers in contaminated cultures of pigmented diatoms maintained in the dark, either in hanging drop cultures or in mass cultures with a rich organic nutrient. Karsten (1901), working with impure diatom cultures, determined growth by making daily cell counts. After the cells had been placed in the dark on a medium containing glycine and glucose, he observed three cells of Navicula perpusilla to increase to nineteen in 6 days, and seven cells of Nitzschia closterium to increase to eighteen in 3 days. Later workers have been inclined to discredit Karsten's observations because he worked with impure cultures, and because he did not let his experiments run for a long enough period to establish conclusively that the organisms were capable of using an external substrate for growth. Karsten also reported that Nitzschia palea, unlike the diatoms previously mentioned, showed only an occasional cell division in darkness. He observed that eleven cells increased to fourteen cells in 2 days, and no further growth was noted after 10 days. Richter (1906) reported that pure cultures of Navicula minuscula showed no significant development after a month in the dark on a mixture of glycerol, asparagine and glucose, but considered that slight growth took place in his pure cultures of $N$. palea during the first day in darkness, in agreement with Karsten's observations on the same organism. Meinhold (1911) and Treboux (1905) were unsuccessful in obtaining growth of diatoms in the dark.

Although he did not specifically attempt to obtain growth of $N$. palea in the dark, von Denffer (1947) observed that one cell division could occur in darkness when the cells were well filled with fatty reserves. Such cells were able to

\footnotetext{
* Present Address: Maritime Regional Laboratory, Halifax, Nova Scotia, Canada.
} 
divide even in distilled water. On the other hand, fat-free cells, obtained by previous starvation in darkness for 8 days, were not capable of dividing in the dark even in the presence of organic nutrient. Von Denffer also observed that the reserves of fat were almost completely utilized in the course of the one cell-division in the dark, and was of opinion that the cell divisions reported for N. palea by Karsten and by Richter were also a result of utilization of intracellular fat. Barg (1943), working with impure cultures of the colourless, and therefore heterotrophic, diatom, $N$. putrida, noted by microscopic observation that glucose, glycerol, oleic acid, sucrose, or raffinose stimulated the production of oil droplets within the cells, but made no mention of any cell multiplication in the presence of these carbon sources. According to Pringsheim (1951), only protein hydrolysates support growth of $N$. putrida, whereas glucose and acetate when present by themselves are not utilized. Pringsheim (1951), in noting that none of the coloured diatoms has been grown heterotrophically, stated that if such heterotrophic species exist they should be looked for among the small species of Navicula and Nitzschia often to be found in habitats rich in decaying organic matter. It is in fact among such diatoms that heterotrophic forms have been found in the present study. This paper deals with the successful heterotrophic cultivation of several small species of pennate diatoms, and a more intensive investigation made with Navicula pelliculosa (Bréb.) Hilse.

\section{EXPERIMENTAL}

\section{Methods}

Medium. In all cases the mineral medium used contained the following concentrations of salts: $\mathrm{K}_{2} \mathrm{HPO}_{4}, 0.02 \%(\mathrm{w} / \mathrm{v}) ; \mathrm{MgSO}_{4} \cdot 7 \mathrm{H}_{2} \mathrm{O}, 0.02 \%(\mathrm{w} / \mathrm{v})$; $\mathrm{Ca}\left(\mathrm{NO}_{3}\right)_{2} \cdot 4 \mathrm{H}_{2} \mathrm{O}, 0 \cdot 1 \%(\mathrm{w} / \mathrm{v})$ in distilled water. Traces of $\mathrm{B}, \mathrm{Mn}, \mathrm{Zn}, \mathrm{Cu}, \mathrm{Mo}$, and $\mathrm{Fe}$, were added. Silicon was added as potassium silicate ('Solution silicate of potash', Eimer \& Amend, New York) to establish a soluble silicon concentration of 1-5 mg. Si/1. before the addition of agar. 1.0\% Bacto-Difco agar was used for the preparation of plates and slopes.

The organic compounds to be tested were incorporated in the above medium. Sterilization was usually carried out by autoclaving at $15 \mathrm{lb}$./sq.in. for $15 \mathrm{~min}$. Seitz filtration was used for those compounds which decompose on autoclaving.

Illumination. Petri plates or test tubes (sloped on racks) were placed under constant illumination of $\mathbf{2 2 5} \mathrm{ft}$.c. provided by 'Daylight' fluorescent tubes.

Temperature. All cultures were grown at $23^{\circ}$.

Gas-phase. In those cases where a $\mathrm{CO}_{2}$-free atmosphere was required the tubes were enclosed in a glass desiccator above $30 \%(w / v) \mathbf{K O H}$, the cover being sealed with vaseline.

\section{General survey}

Forty-two bacteria-free cultures of fresh-water diatoms were obtained in the following manner. Samples of water from ponds and ditches, and suspensions of soil, were streaked on agar plates containing only mineral supple- 
ments, and were incubated under constant illumination. By the use of routine bacteriological streaking techniques a number of cultures of diatoms were isolated. Tests for the presence of bacteria were carried out by transfers into media containing glucose and Tryptone, and by microscopic examination. Each of these isolates was tested for its ability to grow in the dark on agar media containing minerals, supplemented with $0.5 \%$ glucose. The results are summarized in Table 1, and the heterotrophic species are illustrated in Plate 1.

Table 1. Diatom isolates tested for heterotrophic growth

\begin{tabular}{|c|c|c|}
\hline Species & $\begin{array}{c}\text { No. of } \\
\text { isolates }\end{array}$ & $\begin{array}{l}\text { No. of isolates } \\
\text { capable of } \\
\text { unlimited growth } \\
\text { in the dark on } \\
\text { glucose }\end{array}$ \\
\hline $\begin{array}{l}\text { Nitzschia palea (Kütz) W. Smith } \\
\text { or N. Kützingiana Hilse }\end{array}$ & 27 & $\mathbf{0}$ \\
\hline Nitzschia ? fonticola Grun. & 1 & 1 \\
\hline Hantzschia amphioxys (Ehr.) Grun. & 1 & $\mathbf{0}$ \\
\hline Gomphonema paroulum Kütz & $\mathbf{1}$ & $\mathbf{0}$ \\
\hline Navicula pelliculosa (Bréb.) Hilse & 7 & 7 \\
\hline Navicula minima Grun. & 1 & 1 \\
\hline Navicula spp. (different) & 4 & 4 \\
\hline
\end{tabular}

The seven isolates of Navicula pelliculosa were obtained from various localities: four from Connecticut garden soil, one from Connecticut pond water, one from a public fountain in Connecticut, and one from snow from Alaska. Although minor cultural differences between the various strains were observed, it is of interest that all the isolates of this species could grow in the dark on glucose. Since $N$. pelliculosa showed such good growth under these conditions, special attention was given to this species, and a more thorough investigation of heterotrophic growth was carried out with the isolate obtained from Clark's Pond near New Haven, Conn., U.S.A.

\section{Heterotrophic nutrition of Navicula pelliculosa}

Survey of organic carbon sources. The normal mode of nutrition of autotrophic algae is photosynthesis, i.e. the fixation of $\mathrm{CO}_{2}$ using energy derived from light. Conditions for heterotrophy may be obtained in the laboratory by eliminating either light or $\mathrm{CO}_{2}$ so that no photosynthesis can take place, and supplying an organic carbon source that the organism can use for growth. In order to determine what carbon sources might be utilized by $N$. pelliculosa for growth in the absence of light or $\mathrm{CO}_{2}$, a large number of organic compounds were tested individually. Each of these compounds was incorporated with minerals into agar slopes. Tubes so prepared were inoculated and then incubated $(a)$ in air in light; $(b)$ in air in darkness; and $(c)$ in $\mathrm{CO}_{2}$-free air in light. Although one could not be certain that the $\mathrm{KOH}$ removed all traces of $\mathrm{CO}_{2}$, the supply of $\mathrm{CO}_{2}$ was insufficient for photosynthesis, and no growth was ever obtained on mineral media under these conditions. Therefore, any carbon source which supported growth was effective at a $\mathrm{CO}_{2}$ tension considerably below that 
necessary for photosynthesis. The compounds tested in such experiments are listed in the Appendix, with the concentrations employed and explanations where necessary.

Of the sixty compounds tested in this survey, only three were found to support heterotrophic growth of $N$. pelliculosa. Glucose was effective both in the dark, and in light in the absence of $\mathrm{CO}_{2}$. Glycerol or fructose supported growth in absence of $\mathrm{CO}_{2}$ only in light; neither compound was utilized in the dark. The results are summarized in Table 2. It is thus apparent that, although the organism normally grows photosynthetically, it can also grow on glucose in the complete absence of photosynthesis. For utilization of glycerol or fructose, light but not $\mathrm{CO}_{2}$ is necessary; it cannot be stated definitely whether all photosynthetic processes are excluded in these last cases.

Table 2. Carbon compounds which supported heterotrophic growth of $\mathbf{N}$. pelliculosa

\begin{tabular}{|c|c|c|c|}
\hline \multirow[b]{3}{*}{ Control } & \multirow{2}{*}{$\begin{array}{c}\text { Autotrophy } \\
\text { Light }\left(+\mathrm{CO}_{2}\right)\end{array}$} & \multicolumn{2}{|c|}{ Heterotrophy } \\
\hline & & Light $\left(-\mathrm{CO}_{2}\right)$ & Dark $\left(+\mathrm{CO}_{2}\right)$ \\
\hline & $+t$ & - & - \\
\hline Glucose & $+t$ & + & $+t$ \\
\hline Glycerol & ++ & + & - \\
\hline Fructose & ++ & + & - \\
\hline
\end{tabular}

Glucose utilization. In order quantitatively to compare growth rates and total growth on various glucose concentrations in the light $\left(+\mathrm{CO}_{2}\right.$ and $-\mathrm{CO}_{2}$ ) and in the dark, colorimetric determinations were made of the amount of pigment extractable from cells on the surface of each agar slope. For this purpose, $10 \mathrm{ml}$. acetone were used per tube, the extraction being carried out in darkness at room temperature, with occasional shaking, for $1 \mathrm{hr}$. The extract was then decanted and its optical density determined by means of a Klett colorimeter with a ruby glass filter no. 66 .

Six tubes of each glucose concentration were set up under each of the three conditions described on p. 307. On each day when growth was to be measured, one tube of each set was sacrificed for pigment determination. Care was taken in the preparation and inoculation of the slopes to insure maximum uniformity within the sets, in order to minimize the individual variation between tubes. Growth of N.pelliculosa in darkness on glucose, as measured by colorimetric determination of the pigment extracted, is given in Table 3 . It can be seen that as little as $0.0073 \%$ glucose was enough to support some growth of $N$. pelliculosa, but with increasing glucose concentration growth was increased. A glucose concentration between 0.2 and $2.0 \%$ was apparently optimal for 35 days' growth in the dark.

Fig. $1(a, b, c)$ illustrates growth with and without glucose $(1.85 \%)$ in $(a)$ light $+\mathrm{CO}_{2}$, (b) darkness $+\mathrm{CO}_{2}$, (c) light $-\mathrm{CO}_{2}$. Essentially comparable results were obtained with other glucose concentrations. There was no growth in the absence of glucose, either in the dark or in light $-\mathrm{CO}_{2}$. There was a shorter lag in light than under the two heterotrophic conditions. Since cell 
Table 3. Growth of $\mathrm{N}$. pelliculosa in the dark on glucose

(Relative growths were measured in terms of pigment production)

\begin{tabular}{|c|c|c|c|c|c|}
\hline \multirow{3}{*}{$\begin{array}{c}\text { Glucose } \\
\text { concentration } \\
(\%)\end{array}$} & \multicolumn{5}{|c|}{ Days after inoculation } \\
\hline & 12 & 15 & 19 & 27 & 35 \\
\hline & \multicolumn{5}{|c|}{ Relative growth (Klett colorimeter units) } \\
\hline 0 $\quad$. & $\mathbf{0}$ & 0 & 0 & $\mathbf{0}$ & $\mathbf{0}$ \\
\hline 0.0014 & $\mathbf{0}$ & $\mathbf{0}$ & $\mathbf{0}$ & $\mathbf{2}$ & 8 \\
\hline 0.0073 & $\mathbf{5}$ & 12 & $\boldsymbol{\theta}$ & 10 & 14 \\
\hline 0.036 & 11 & 21 & 36 & 37 & 48 \\
\hline $0 \cdot 184$ & 13 & 47 & 59 & $\mathbf{5 5}$ & 80 \\
\hline 0.92 & 25 & 57 & 67 & 69 & 92 \\
\hline $\mathbf{1} \cdot \mathbf{8 5}$ & 24 & 48 & 69 & 75 & 83 \\
\hline 8.7 & 16 & $\mathbf{3 3}$ & 45 & 61 & 66 \\
\hline $7 \cdot 5$ & $\mathbf{0}$ & $\mathbf{0}$ & $\mathbf{0}$ & 0 & 5 \\
\hline
\end{tabular}
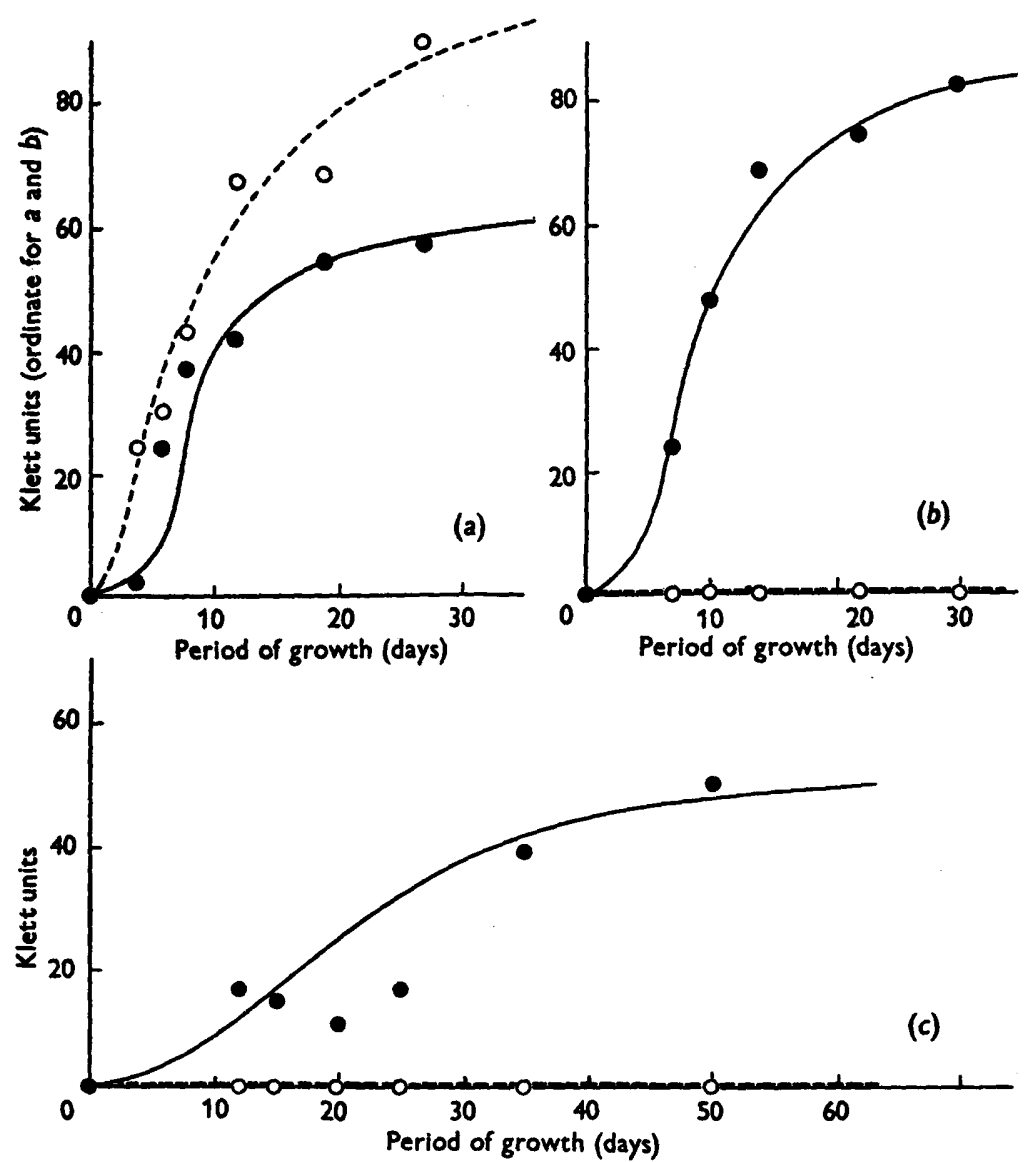

Fig. 1. Growth of $N$. pelliculosa (as measured by optical density of pigment extract). $(a)$ in light $+\mathrm{CO}_{2} ;(b)$ in darkness $+\mathrm{CO}_{2} ;(c)$ in light $-\mathrm{CO}_{2}$. With $1.85 \%$ glucose, $\mathrm{O}$; without glucose addition, $O$. 
pigments tend to bleach in light more rapidly in the presence of glucose, growth in light (as measured by pigment density) is apparently poorer on glucose than on minimal medium. Following the lag phase, the growth rates on glucose $+\mathrm{CO}_{2}$ in light or darkness were similar, but growth in light $-\mathrm{CO}_{2}$ proceeded much more slowly, possibly indicating a requirement for $\mathrm{CO}_{2}$ independent of direct photosynthesis.

Glycerol and fructose utilization. Since glycerol supported growth in light in absence of $\mathrm{CO}_{2}$, but not in the dark, it was considered possible that glycerol and some other compound might together permit growth in darkness. Consequently, in a series of experiments a number of compounds such as sugars, fatty acids, ATP, Tryptone, casein hydrolysate, and various concentrations of inorganic phosphate $\left(0.02 \%\right.$ to $\left.0.1 \% \mathrm{~K}_{2} \mathrm{HPO}_{4}\right)$ were tested as supplements to glycerol media. (Some of the combinations are incorporated in the Appendix.) In all cases the results were negative. Glycerol, alone or supplemented with other compounds, would not support growth in darkness.

An attempt was made to obtain utilization of fructose in the dark by adding it in various concentrations to media containing $0.002 \%$ glucose. It was thought that this small amount of glucose might act in a coupled reaction to provide energy for any initial phosphorylation which might be necessary before fructose oxidation could get under way. There was no growth over and above that supported by $0.002 \%$ glucose alone at any of the fructose concentrations tested. It thus appears that light is essential for the heterotrophic utilization of fructose and glycerol by $N$. pelliculosa.

\section{DISCUSSION}

It is not surprising that certain species of chlorophyllous diatoms are able to grow heterotrophically. In any group of algae which occupy as wide a range of habitats as do the diatoms, there are almost certain to be those which can utilize organic carbon compounds of the environment for growth in darkness. However, since their rate of growth would probably be considerably slower than that of many obligate heterotrophs, such algae cannot readily be isolated by simple enrichment techniques, and facultative heterotrophy can only be demonstrated when pure cultures have been obtained (see Allen, 1952).

Although an organism may possess the ability to metabolize an organic compound, it does not follow that the energy or the intermediates so produced would necessarily be available for growth. For instance, although $N$. pelliculosa is unable to utilize lactic, acetic, pyruvic, citric, or succinic acid for heterotrophic growth, each of these substrates can stimulate respiration of this diatom when tested in Warburg manometric experiments (Lewin, unpublished). The organism can thus apparently metabolize such substrates but cannot utilize them for growth. The total free energy from oxidation of lactic acid is not markedly different from that liberated in glucose oxidation, yet lactic acid, unlike glucose, cannot serve as a substrate for growth in darkness. It would therefore seem that the critical factor here is not energy, 
but rather some essential intermediate $(Y)$ which may be formed during glucose oxidation. Possibly this intermediate can be formed heterotrophically in the light when either fructose or glycerol is supplied to the cells. However, compounds such as hexose diphosphate, fructose-6-phosphate, phosphoglyceric acid, and glucose-1-phosphate, which one might have expected to be convertible into the intermediate $(Y)$, did not support heterotrophic growth at all.

The fact that light is required for the heterotrophic utilization of fructose or glycerol by $N$. pelliculosa merits further consideration. It is possible that fructose or glycerol may be first converted by the cells to some intermediate $(X)$. Light may then act by converting $(X)$ into $(Y)$, a hypothetical compound required for growth.

$$
\text { Glycerol or fructose } \longrightarrow(X) \stackrel{\text { Light }}{\longrightarrow}(Y) \longrightarrow \text { Growth. }
$$

If $(X)$ were $\mathrm{CO}_{2}$ then light would be acting in a normal photosynthetic fixation of $\mathrm{CO}_{2}$. However, it is doubtful whether $\mathrm{CO}_{2}$ itself is the intermediate in the photochemical process, since lactic acid, which can be oxidized by N. pelliculosa to $\mathrm{CO}_{2}$ (Lewin, unpublished), cannot support growth under conditions where glycerol or fructose is effective. Some compound other than $\mathrm{CO}_{2}$ would probably be involved if a scheme such as that presented above were operative. Interpretation of this phenomenon is rendered more difficult by the fact that glycerol or fructose shows only slight stimulation to respiration when tested in Warburg manometric experiments (Lewin, unpublished).

Acknowledgment is made to Dr R. A. Lewin for aid in the isolation of the diatoms used in this study, and for the preparation of the electron-micrographs. Some of the material included in this paper was presented as part of a Ph.D. thesis submitted to Yale University in 1952. The author is indebted to Dr E. G. Young, Maritime Regional Laboratory, Halifax, Nova Scotia, for critical assistance in the preparation of this paper. 


\section{APPENDIX \\ Carbon compounds tested for ability to support heterotrophic growth of Navicula pelliculosa}

(The figures in brackets following the concentrations tested are the lowest concentrations (\%) which were inhibitory to growth in light.)

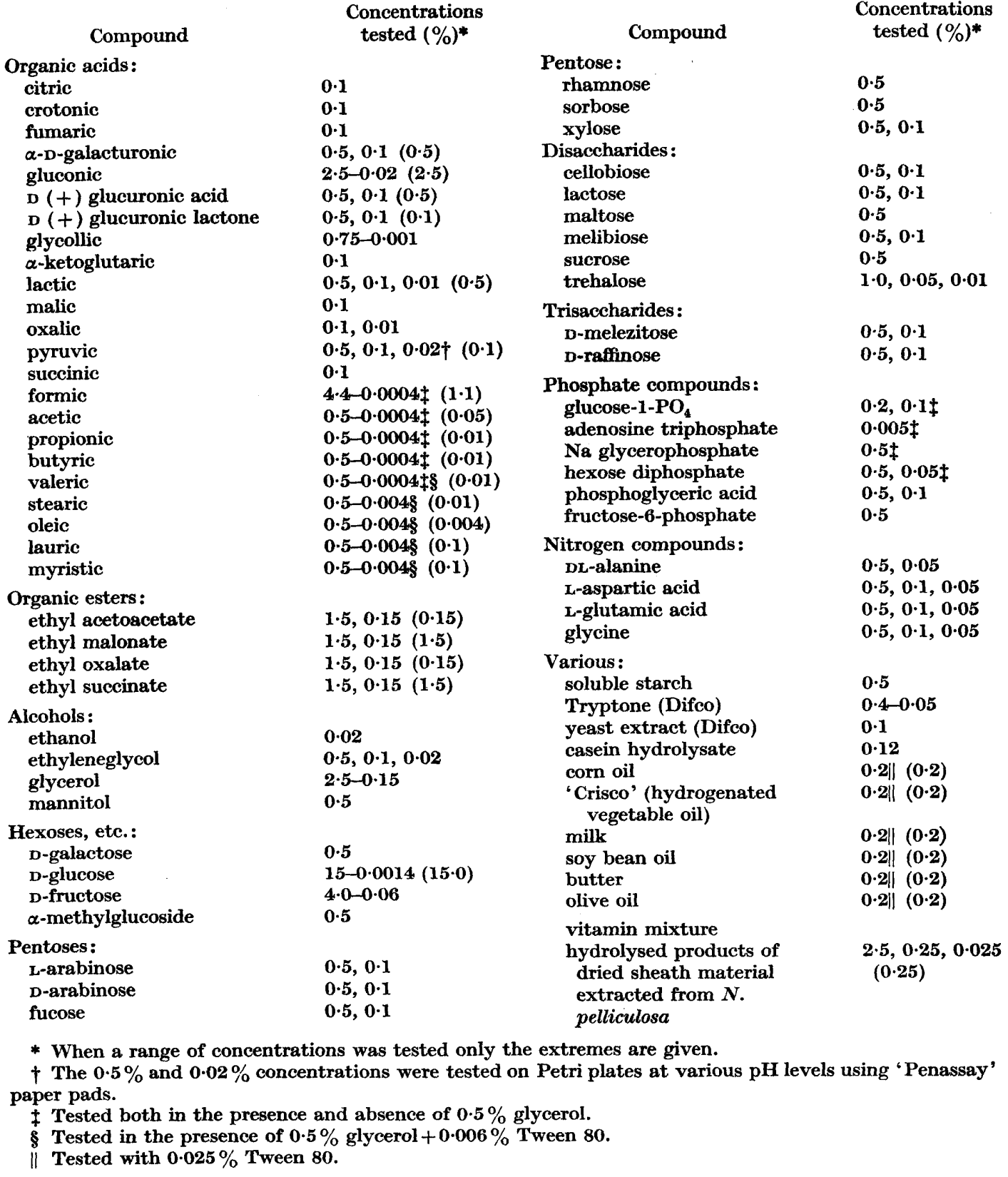


Journal of General Microbiology, Vol. 9, No. 2

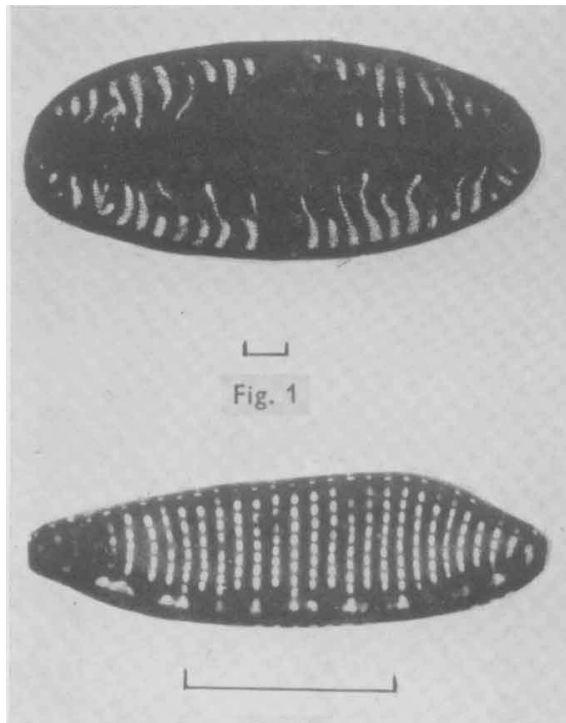

Fig. 3

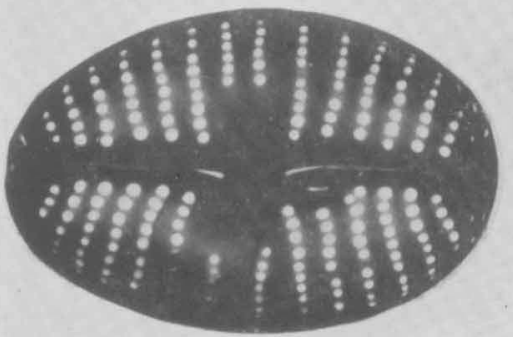

Fig. 5

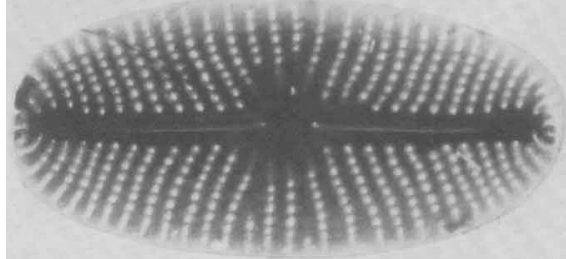

Fig. $7 a$

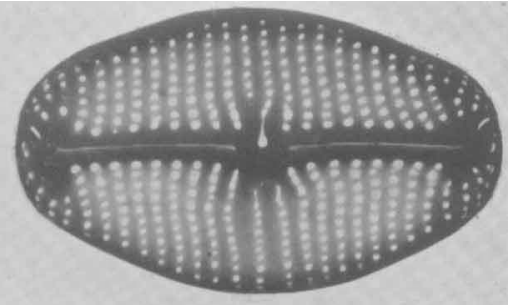

Fig. 2

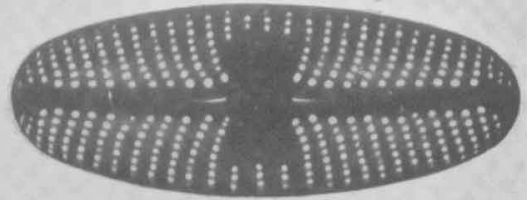

Fig. 4

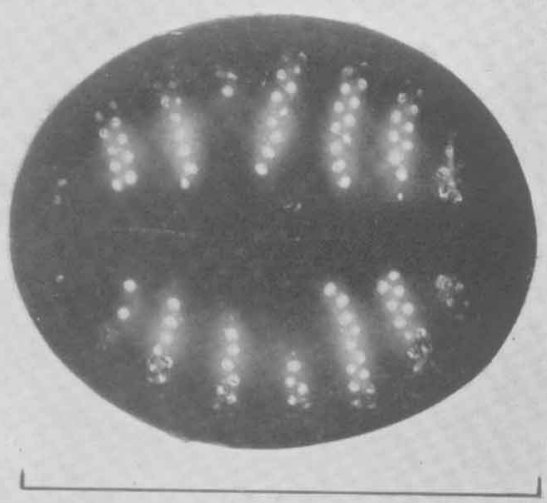

Fig. 6

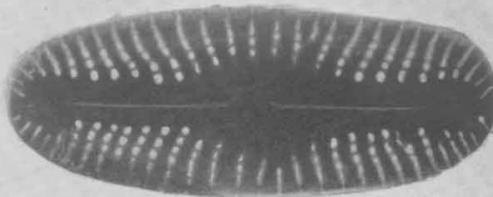

J. C. Lewin--Heterótrophy in diatoms. Plate 1 


\section{REFERENCES}

Aluen, M. B. (1952). The cultivation of Myxophyceae. Arch. Mikrobiol. 17, 34.

BARg, T. (1943). Über den Fettgehalt der Diatomeen. Ber. dtsch. bot. Ges. 61, 13. Benecke, W. (1900). Utber farblose Diatomeen der Kieler Föhrde. Jb. wiss. Bot. 35, 535.

KARSTEN, G. (1901). Utber farblose Diatomeen. Flora, 89, 404.

Meinhoud, T. (1911). Beiträge zur Physiologie der Diatomeen. Beitr. Biol. Pf. 10, 353.

Miquel, P. (1892). De la culture artificielle des Diatomées. Le Diatomiste, 1, 93.

Pringsheim, E. G. (1951). Utber farblose Diatomeen. Arch. Mikrobiol. 16, 18.

Richter, O. (1906). Zur Physiologie der Diatomeen. S.B. Akad. Wiss. Wien. Abt. I. $115,27$.

Treboux, O. (1905). Organische Säuren als Kohlenstoffquelle bei Algen. Ber. dtsch. bot. Ges. 23, 432.

von DeNFFer, D. (1947). Die planktische Massenkultur pennater Grunddiatomeen. Arch. Mikrobiol. 14, 159.

\section{EXPLANATION OF PLATE}

Electron-micrographs of diatom species capable of heterotrophic growth. Each scale line represents $5 \mu$.

Fig. 1. ? Navicula $\mathrm{sp.} \times 850$.

Fig. 2. Navicula sp. (section minusculae) $\times 4450$.

Fig. 3. Nitzschia ? fonticola Grun. $\times 4 \mathbf{4 3 3 0}$.

Fig. 4. Navicula minima Grun. $\times 6250$.

Fig. 5. Navicula sp. (section minusculae $?=N$. muralis) $\times 8170$.

Fig. 6. ? Navicula sp. $\times 10,400$.

Fig. 7. Navicula pelliculosa (Bréb.) Hilse. (a) $\times 6500$ (from Connecticut pond); $(b) \times 6125$ (from Alaska snow).

(Received 27 April 1953) 